\title{
Review \\ Vibrational Imaging Techniques for the Characterization of Hard Dental Tissues: From Bench-Top to Chair-Side
}

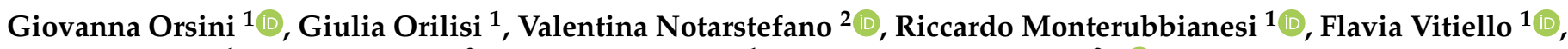 \\ Vincenzo Tosco ${ }^{1}$, Alessia Belloni ${ }^{2}$, Angelo Putignano ${ }^{1}$ and Elisabetta Giorgini ${ }^{2, *(D)}$ \\ 1 Department of Clinical Sciences and Stomatology, Polytechnic University of Marche, 60126 Ancona, Italy; \\ g.orsini@staff.univpm.it (G.O.); g.orilisi@pm.univpm.it (G.O.); r.monterubbianesi@univpm.it (R.M.); \\ f.vitiello@pm.univpm.it (F.V.); v.tosco@univpm.it (V.T.); a.putignano@staff.univpm.it (A.P.) \\ 2 Department of Life and Environmental Sciences, Polytechnic University of Marche, 60131 Ancona, Italy; \\ v.notarstefano@staff.univpm.it (V.N.); a.belloni@pm.univpm.it (A.B.) \\ * Correspondence: e.giorgini@staff.univpm.it
}

\section{check for}

updates

Citation: Orsini, G.; Orilisi, G.; Notarstefano, V.; Monterubbianesi, R.; Vitiello, F.; Tosco, V.; Belloni, A.; Putignano, A.; Giorgini, E.

Vibrational Imaging Techniques for the Characterization of Hard Dental Tissues: From Bench-Top to Chair-Side. Appl. Sci. 2021, 11, 11953. https://doi.org/10.3390/ app112411953

Academic Editor: Cosimo Nardi

Received: 16 November 2021

Accepted: 13 December 2021

Published: 15 December 2021

Publisher's Note: MDPI stays neutral with regard to jurisdictional claims in published maps and institutional affiliations.

Copyright: (C) 2021 by the authors. Licensee MDPI, Basel, Switzerland. This article is an open access article distributed under the terms and conditions of the Creative Commons Attribution (CC BY) license (https:/ / creativecommons.org/licenses/by/ $4.0 /)$.
Abstract: Currently, various analytical techniques, including scanning electron microscopy, X-Ray diffraction, microcomputed tomography, and energy dispersive $\mathrm{X}$-ray spectroscopy, are available to study the structural or elemental features of hard dental tissues. In contrast to these approaches, Raman Microspectroscopy (RMS) has the great advantage of simultaneously providing, at the same time and on the same sample, a morpho-chemical correlation between the microscopic information from the visual analysis of the sample and its chemical and macromolecular composition. Hence, RMS represents an innovative and non-invasive technique to study both inorganic and organic teeth components in vitro. The aim of this narrative review is to shed new light on the applicative potential of Raman Microspectroscopy in the dental field. Specific Raman markers representative of sound and pathological hard dental tissues will be discussed, and the future diagnostic application of this technique will be outlined. The objective and detailed information provided by this technique in terms of the structure and chemical/macromolecular components of sound and pathological hard dental tissues could be useful for improving knowledge of several dental pathologies. Scientific articles regarding RMS studies of human hard dental tissues were retrieved from the principal databases by following specific inclusion and exclusion criteria.

Keywords: Raman Microspectroscopy; Fourier Transform Infrared spectroscopy; vibrational spectroscopy; enamel; dentin; hard dental tissues; dental genetic anomalies; early enamel lesions; dental caries

\section{Introduction}

In recent years, vibrational spectroscopic techniques, such as Raman Microspectroscopy (RMS) and Fourier Transform Infrared (FTIR) spectroscopy, have been employed as emerging tools for studies in the biomedical field, including those on the structural and macromolecular composition of tissues and cells [1-3]. Both of these non-destructive and label-free analytical techniques, based on the interaction between matter and electromagnetic radiation, provide relevant information on the chemical bonds, and hence the functional groups of the macromolecules within the analyzed sample [4,5].

RMS is defined as a scattering technique; indeed, it measures the two-photon inelastic light scattering produced when the photons from monochromatic electromagnetic radiation interacting with matter are scattered from the samples with an energy higher or lower in respect to the incident one [6-8]. It does not require extrinsic contrast-enhancing agents and allows one to obtain reproducible and reliable results on the chemical composition of the sample, with minimal to no preparation $[8,9]$. On the other hand, FTIR is based on the absorption of electromagnetic radiation in the IR range; hence, it is an absorption spectroscopy $[8,10]$. Infrared spectroscopy can be applied in transmission mode for samples transparent to the radiation, or in reflectance mode in the case of solid and 
non-transparent materials [10]. In this latter case, IR spectra are collected using Attenuated Total Reflectance-Fourier transform InfraRed spectroscopy (ATR-FTIR), a contact sampling method that exploits a crystal with a high refractive index; this technique is based on the analysis of the 'evanescent wave', originating from the crystal and penetrating within the material for a fraction of its wavelength [11,12]. Infrared and Raman techniques also differ in the measured molecular vibrations, with the first detecting changes in the dipole moment, and the second detecting variations in the polarizability of the molecule [13]. This difference means that Raman spectroscopy can detect the symmetric vibrations of non-polar groups, while IR spectroscopy better measures the asymmetric vibrations of polar groups [8].

Therefore, RMS and FTIR are completely complementary techniques; the different physical phenomena they rely on determine differences in terms of provided information and applicability; hence, each of them show specific advantages and disadvantages, also in their application to biological systems [4,10]. For example, IR spectra are not affected by fluorescence, which often influences Raman measurements [14]. On the other hand, RMS is more suitable for the analysis of samples in aqueous solution; in fact, Raman spectra are not altered by water, which conversely massively influences IR spectra and requires complex subtraction procedures [2,14].

In the last decades, Raman and FTIR instrumentations have been significantly improved by their coupling with optical microscopes that let perform the imaging analysis. In this way, by mapping micro-areas of interest, it is possible to combine the information derived from the morphological analysis of the sample with its punctual chemical composition $[15,16]$. However, given the different physical phenomena on which the two techniques rely, IR spectroscopy requires 5-10 $\mu$ m-thick tissue sections for analysis in transmission mode $[9,17,18]$, while RMS can be applied to solid and thicker samples. Moreover, since RMS is based on light scattering, it can be exploited in a confocal mode by focusing the laser not only on the surface of the sample, but also at a specific depth [7,19]. In addition, RMS provides maps with a better spatial resolution than FTIR, allowing the detection of biological modifications which cannot be highlighted using more traditional techniques [19]. In fact, while FTIR shows some limitations due to the diffraction limit, which restricts the achievable spatial resolution to $10-20 \mu \mathrm{m}$, the shorter wavelengths exploited by RMS yield a diffraction-limited spatial resolution of $1 \mu \mathrm{m}$ or less, depending on the objective $[3,15]$.

Vibrational techniques have also been employed in dentistry for the analysis and chemical characterization of both dental materials and teeth components [17,20-23]. Indeed, FTIR was used to track the polymerization kinetics of dental resin composites [24-27] and adhesives [28,29]. Furthermore, the IR technique was exploited to determine the effects of materials containing nanohydroxyapatite on the enamel surface [30,31], to analyze new generation biomimetic materials mimicking the mineral organic dentin and enamel complex [32], and to characterize implant materials, biopolymers, ceramics, and resin nanocomposites [33-35]. Regarding RMS, its applicative potential in the dental field has not yet been fully exploited, even if recent results suggest a promising use of this technique for the characterization of hard dental tissues, also for diagnostic purposes [13,36]. RMS has been demonstrated to be a successful tool for the diagnosis of oral cancer [37] and for the study of tooth mineralized tissues, due to its sensitivity in the analysis of both mineral and organic components, as well as for the detection of early caries by using innovative fiber optical probes [9,38-40] and the evaluation of caries progression $[19,41]$.

Other techniques have already been exploited for the study of dental tissues, such as scanning electron microscopy [42-44], X-Ray diffraction [42,45], microcomputed tomography [46,47], and energy dispersive X-ray spectroscopy [36,48]: all these imaging techniques can obtain high-resolution information on the morphological features and/or the elemental composition of the samples of interest. Conversely, RMS can acquire maps, both on the surface of the tooth or at depth, that provide a morpho-chemical correlation between the microscopic information derived from the visual analysis of the sample and 
its chemical and macromolecular composition, at the same time and on the same sample. In this light, RMS represents an innovative and non-invasive technique to study both inorganic and organic teeth components in vitro [49]. Therefore, this narrative review aims to summarize the application of Raman Microspectroscopy in the dental field. In particular, specific Raman markers representative of sound and pathological hard dental tissues will be discussed. The possibility of simultaneously obtained detailed and objective information on biochemical structure and chemical composition is crucial to relate the morphological alterations characterizing the different dental pathologies with variations in terms of the chemical features of hard dental tissues. Moreover, the benefits and the limitations of this technique will be outlined. Finally, this narrative review may be a useful starting point for new research on this topic and for possible future diagnostic application in clinical practice: from bench-top to chair-side.

\section{Materials and Methods}

This article represents a narrative review regarding recent applications of Raman Microspectroscopy on sound and pathological hard dental tissues. It was performed in accordance with the Scale for the Assessment of Narrative Review Articles [50,51]. An electronic literature search was performed on PubMed, Scopus, and Web of Science from January 2016 to October 2021; the scientific publications earlier than 2016 were cited only when they were essential for advancing the discussion. A combination of the following keywords was used: "Raman" OR "ATR-FTIR" AND "dental lesions" OR "human teeth application" OR "tooth structure". Related articles cited in the reference list of relevant studies were manually searched. Articles were selected in two phases: title and abstract screening and then full-text screening; if the content of the abstract was unclear, the article was selected for full-text review. All scientific articles were evaluated according to specific predetermined inclusion and exclusion criteria. The inclusion criteria were: (1) articles published from January 2016 to October 2021, (2) dental lesions and dental structure analyzed by Raman Microspectroscopy or ATR-FTIR spectroscopy, (3) analysis of human teeth, (4) English language, and (5) full-text publication. The exclusion criteria were: (1) not human teeth, (2) duplicate literature and duplicate data, (3) full-text not accessible, and (4) not available in English. There were no disagreements during the article selection process.

\section{RMS and ATR-FTIR Characterization of Hard Dental Tissues}

Enamel and dentin are the major components of the human dental crown, whereas dentin and cementum are present in the human dental root. Enamel represents the most mineralized tissue of the human body, with a composition up to $96-97 \%$ (by weight) inorganic matter, $2-3 \%$ water, and only $1 \%$ non-collagenous organic material $[52,53]$. The main component of the enamel mineral phase is crystalline bundles of hydroxyapatite (HA) in a hexagonal shape; hydroxyapatite is a mineral form of calcium apatite with a chemical formula $\mathrm{Ca}_{5}\left(\mathrm{PO}_{4}\right)_{3}(\mathrm{OH})$, present in teeth and bones. Enamel mineralization is crucial since a reduction in mineral content could lead to caries susceptibility and dental lesions. Moreover, variation in mineralization may manifest itself through the formation of white spot lesions (WSLs), which also impact teeth aesthetics [54]. Dentin is a composite material containing $70 \%$ mineral components, in form of mineral nanocrystallites, and $20 \%$ protein matrix, predominantly formed by cross-linked type I collagen $(90 \%$ of the whole dentin protein fraction) [41]. Cementum is a mineralized tissue covering the entire root surface and consists of approximately 50\% inorganic matrix (HA) and $50 \%$ organic matrix (collagen, predominantly type I, and non-collagenous proteins) and water $[53,55]$.

In-depth knowledge of the extent and severity of dental disorders and alterations of dental structures may provide valuable information for treatment procedures. To this extent, several authors have investigated the chemical composition of human teeth in terms of decay, demineralization/remineralization processes, and disease using various analytical methods [56-59]. Among all, RMS represents an innovative technique, allowing 
the study of both inorganic and organic components. Since the spectral profile and the peaks' position can be influenced by composition and structure [60], thus making their interpretation challenging, the detailed analysis of the spectral bands related to the chemical composition of the different dental components is mandatory.

In Figure 1, the main IR and Raman bands representative of enamel, dentin, and cementum in sound teeth are reported. Regarding enamel, the main Raman bands are assigned to phosphates $\left(\mathrm{PO}_{4}{ }^{3-}, 960 \mathrm{~cm}^{-1}\right)$, and A- $\left(\mathrm{CO}_{3}{ }^{2-}, 1102 \mathrm{~cm}^{-1}\right)$ and B-type $\left(\mathrm{CO}_{3}{ }^{2-}\right.$, $1070 \mathrm{~cm}^{-1}$ ) carbonate groups in HA [61], with the latter representing the $v_{1}$ symmetric stretching mode of $\mathrm{CO}_{3}{ }^{2-}$ ions replacing $\mathrm{PO}_{4}{ }^{3-}$ in the apatite lattice [62]. Carbonate substitution affects HA in terms of solubility and reactivity [63]. Significant changes in the intensities of these bands were found in carious lesions with respect to healthy enamel and were mainly attributed to demineralization-induced alterations of enamel crystallite morphology and/or orientation $[13,64,65]$. It is well known that crystallinity increases when crystals are larger and/or more perfect, and when there is less substitution [66]. Moreover, in Raman enamel spectra, a weak band at $1660 \mathrm{~cm}^{-1}$, attributable to the amide I band and hence to the organic matrix, can be detected. The Raman spectrum of dentin is characterized by bands at $1660 \mathrm{~cm}^{-1}, 1450 \mathrm{~cm}^{-1}$, and $1242 \mathrm{~cm}^{-1}$ (attributable to collagen) and $1070 \mathrm{~cm}^{-1}\left(\mathrm{CO}_{3}{ }^{2-}\right)$ and $960 \mathrm{~cm}^{-1}\left(\mathrm{PO}_{4}{ }^{3-}\right.$ of hydroxyapatite). Finally, cementum shows Raman bands at $960 \mathrm{~cm}^{-1}$, and $1452 \mathrm{~cm}^{-1}$ and $1660 \mathrm{~cm}^{-1}$, the first assigned to the mineral component and the other two to the organic matrix [13].

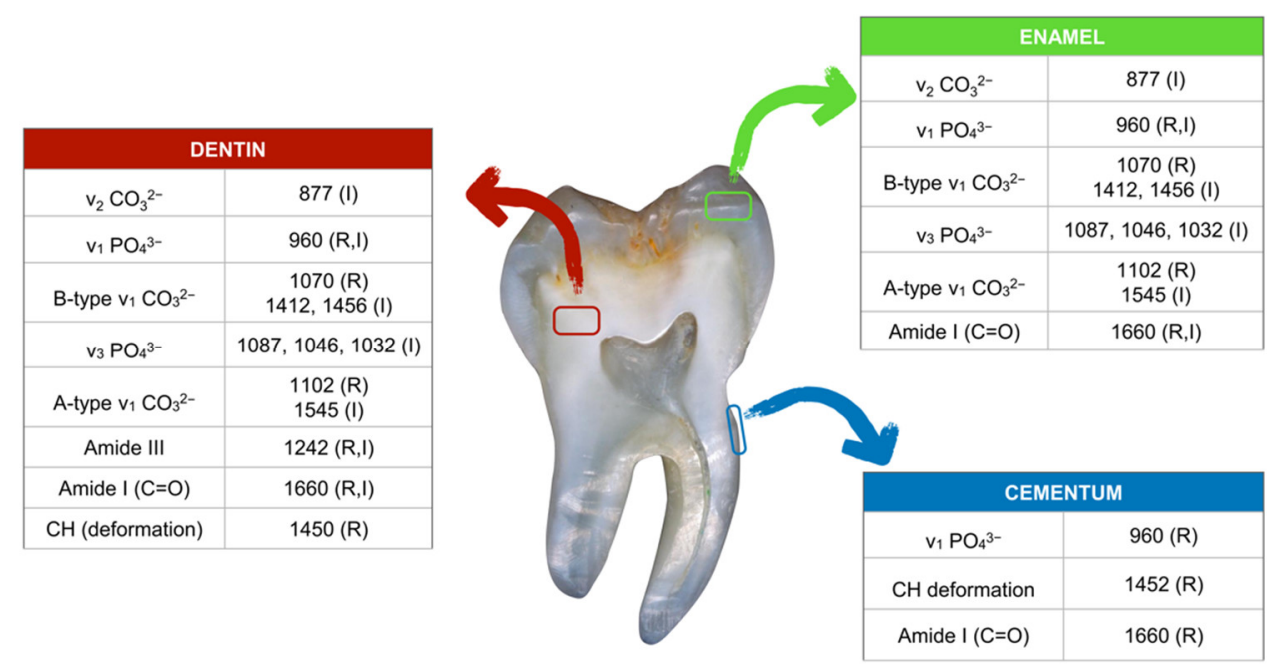

Figure 1. Main Raman (R) and IR (I) peaks of enamel, dentin, and cementum, together with the corresponding vibrational modes ( $v$ : stretching vibration).

By the analysis of Raman spectra, some parameters, such as the full width at half maximum of a single band (FWHM) and band ratios obtained using the areas (A) or the intensities (I) of the most significant bands, can be calculated and used as markers to provide accurate diagnostic information related to diseases affecting dental tissues (Figure 2). Among all, the main analyzed parameters are mineral/matrix $\left(\mathrm{A}_{960} / \mathrm{A}_{1660}\right)$, crystallinity (inversely proportional to $\left.\mathrm{FWHM}_{960}\right), \mathrm{P}\left(\mathrm{I}_{960}\right)$, and carbonate-to-phosphate ratio $(\mathrm{C} / \mathrm{P})$ or gradient in mineral content $(\mathrm{GMC})\left(\mathrm{I}_{1070 / \mathrm{I}_{960}}\right)$ [48]. The mineral/matrix ratio $(\mathrm{M} / \mathrm{M})$ is related to the amount of the mineral component with respect to the organic one. It is calculated as the ratio between the area of the band at $960 \mathrm{~cm}^{-1}$, which is the most intense mineral band of HA (attributed to phosphates), and that of the amide I band centered at $1660 \mathrm{~cm}^{-1}$, [67]. This ratio is used to describe the mineral transitions in affected carious dentine, from the transparent zone into the normal zone $[68,69]$. Indeed, Liu et al. found that the mineral component is higher within the sub-transparent zone than in normal and transparent zones [68]. Crystallinity (C) is correlated with the degree of order within the mineral crystals and represents a critical component of HA, since ion substitution may introduce structural distortions. This parameter is directly proportional to the inverse 
of the full width at half maximum (FWHM) of the above-mentioned band centered at $960 \mathrm{~cm}^{-1}$, meaning that a narrow band width indicates a high mineral crystallinity and vice versa [41]. In the studies reported by Al-Obaidi et al. and Slimani et al., the degree of $C$ was determined in enamel by measuring changes in the peaks ratio of the symmetric mode of phosphate at $960 \mathrm{~cm}^{-1}$ over $950 \mathrm{~cm}^{-1}[61,70]$. The carbonate-to-phosphate ratio (C/P), or gradient in mineral content (GMC), calculated as the ratio between the intensities of the bands centered at $1070 \mathrm{~cm}^{-1}$ and $960 \mathrm{~cm}^{-1}$ attributed to carbonate and phosphate groups in HA, respectively, indicates the extent of carbonate incorporation in the HA lattice, and curve-fitting of the carbonate band reveals whether the carbonate has replaced hydroxide (A-type) or phosphate (B-type) in the apatite lattice. During the demineralization process, a progressive increase of $\mathrm{C} / \mathrm{P}$ occurs, due to the substitution of $\mathrm{CO}_{3}{ }^{2-}$ for $\mathrm{PO}_{4}{ }^{3-}$ in $\mathrm{HA}$ (type B substitution) [71,72]. Almhöjd et al. observed different values of this ratio in sound and carious dentine, the latter showing lower values with respect to sound dentine [69]. In addition, the intensity of the peaks at $1246 \mathrm{~cm}^{-1}, 1450 \mathrm{~cm}^{-1}$, and $1655 \mathrm{~cm}^{-1}$ (attributed to amide III, $\mathrm{CH}_{2}$ groups, and amide I, respectively) are employed to evaluate structural organization and relative amount of collagen. In more detail, the amide I/amide III ratio (calculated as the ratio between the area of amide I and amide III bands) is related to collagen organization, while the amide III $/ \mathrm{CH}_{2}$ and amide $\mathrm{I} / \mathrm{CH}_{2}$ ratios indicate differences in collagen structure and quality $[73,74]$.

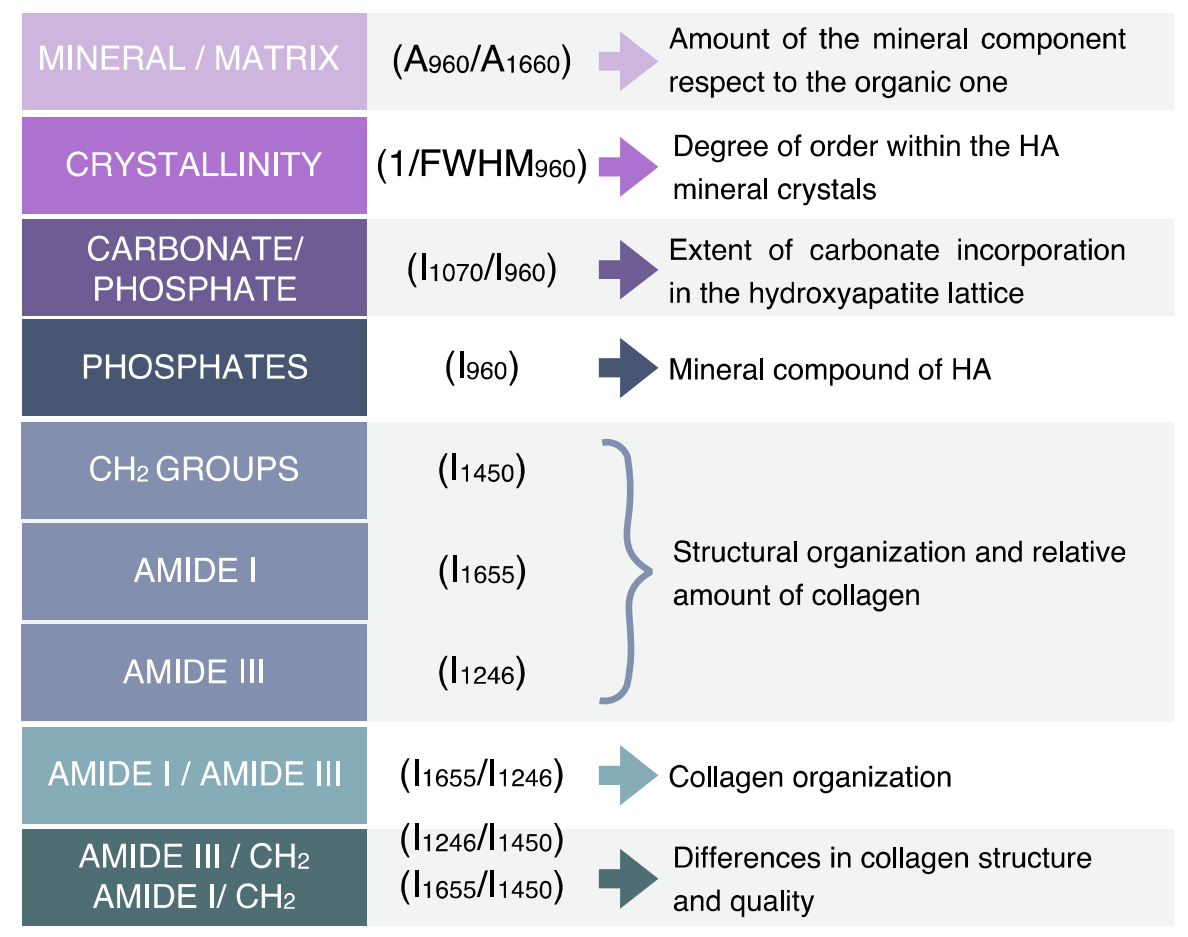

Figure 2. Raman-derived markers for the characterization of hard dental tissues (I: intensity of the band; A: area of the band; and FWHM: full width at half maximum).

\section{Morpho-Chemical Correlation between Histological and Spectral Features of Hard Dental Tissues}

Histological techniques have long been an integral part of dental research [75,76]. However, few articles in the scientific literature have reported the correlation between histological analysis and spectroscopic evaluation. Hewko et al. conducted a study on dental caries, comparing the histological appearance, optical coherence tomography, and Raman spectroscopic findings, and asserted that the peaks observed by Raman spectroscopy could confirm the histological diagnosis of early dental caries [77]. The results showed that the joint use of these methods allows the collection of significantly more data about pathological processes in mineralized tissues, as well as the assessment of the features of mineralization variation [77]. 


\section{Raman Imaging on Sound Hard Dental Tissues}

Besides evaluating the chemical composition of samples by the identification of specific bands, RMS allows one to map specific areas within the analyzed sample by creating false color images, defined as Raman maps, in which the intensities of individual peaks are topographically correlated to the morphology of the mapped area. In this way, it is possible to analyze non-homogeneous samples, such as tissues and cells, in high-resolution to associate chemical composition with morphology [48].

Orilisi et al. obtained RMS maps on the vestibular and lingual sides of sound permanent teeth (Figure 3) [48]. The authors concluded that the lowest values of $C$ were displayed by the dentin regions, while homogenous values were found in the enamel of both vestibular and lingual sides. Moreover, an increase in carbonate content was associated with a decrease in $C$; indeed, dentin showed lower values for $C$ and $M / M$ but had a higher $\mathrm{C} / \mathrm{P}$ value with respect to enamel.

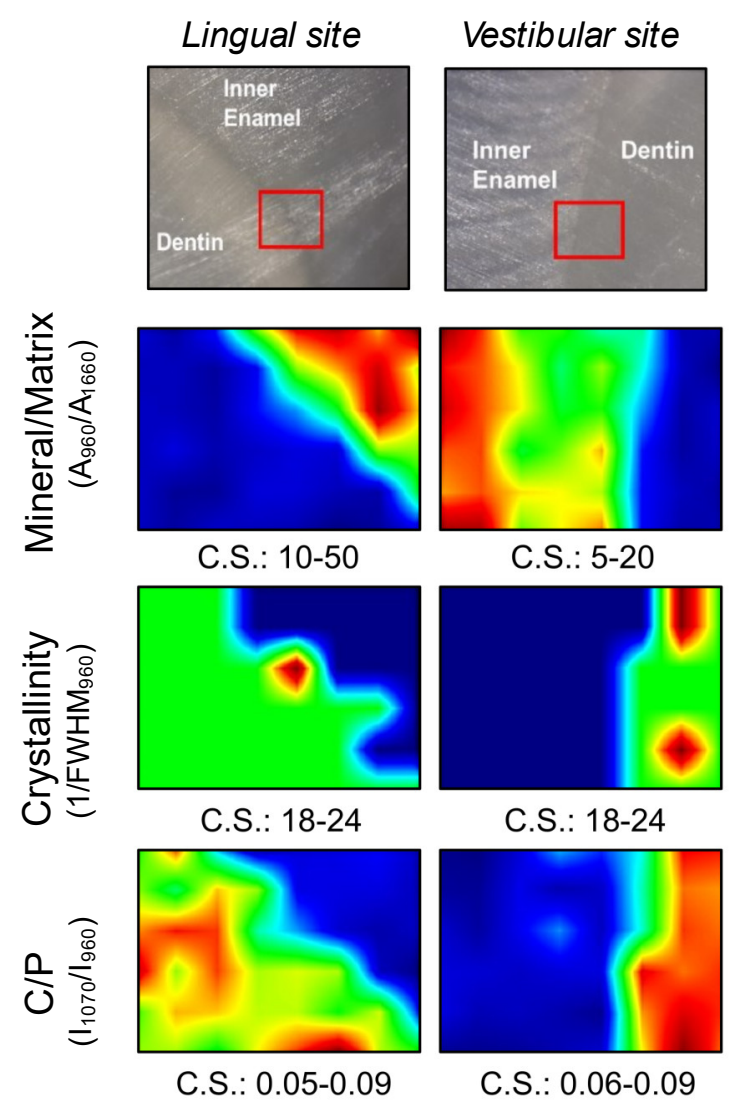

Figure 3. Raman mapping analysis of representative areas at the inner enamel/dentin interfaces in vestibular and lingual sites of permanent teeth. Photomicrographs reporting the selected areas (red rectangles, $241.5 \mathrm{~mm} \times 167 \mathrm{~mm}$ ) and corresponding false-color images $(241.5 \mathrm{~mm} \times 167 \mathrm{~mm})$ showing the topographical distribution of mineral/matrix (A960/A1660), crystallinity (inversely proportional to FWHM960), and C/P (carbonates/phosphates, I1070/I960) spectral features. Different color scales (C.S.) were used for a better interpretation of the data: exact values are reported below each map (black/blue color corresponds to the lowest values, green intermediate, and red/dark red to the highest values) [48].

Similar results emerged in the study of Slimani et al., in which the authors collected Raman maps of the dentin-enamel junction (DEJ) of healthy enamel [70]; they found a transition zone with a thickness of ca. $50 \mu \mathrm{m}$, in which evident variation in terms of mineral and organic components was observed. In general, enamel is characterized by high values of $\mathrm{C}$, due to the presence of well-arranged $\mathrm{HA}$, while dentin is characterized by the lowest values. Furthermore, $\mathrm{C}$ slowly decreased from the enamel border to half of the transition 
zone and then dropped down in dentin; the signals related to phosphates followed the same pattern but with a large decrease from the halfway point. An opposite trend was shown by the collagen crosslink signal, which increased considerably from the enamel border to dentin, varying over $10 \mu \mathrm{m}$ inside the transition zone. The signals related to the organic component also increased from the enamel border to dentin, reaching the highest value of $10 \mu \mathrm{m}$ close to the end of the transition zone [70].

The mineral composition is not homogeneous within sound enamel tissue; however, more crystallinity (greater mineral crystal size) and greater mineral crystal perfection are observed towards the tooth surface, whereas the mineral apatites are less crystalline and have more carbonate imperfection in the crystal lattice near the enamel-dentin junction [78]. Moreover, enamel has less substituted lattice compared to dentin, indicating the presence of mineral crystals with greater stoichiometric perfection in enamel when compared to dentin [78].

\section{RMS Characterization of Dental Lesions}

Hard dental tissues can be subjected to different factors that influence the normal chemical phenotype. Amelogenesis (AI) and dentinogenesis (DI) imperfectae represent a heterogeneous group of genetic conditions characterized by defects in the formation of enamel and dentin, respectively, in teeth of both dentitions [79,80]. On the other hand, enamel and dentin mineralization can be affected, after their eruption, by different extrinsic factors, such as poor oral hygiene, alcohol and acidic beverage consumption, high intake of dietary carbohydrates, and dental trauma, all leading to early demineralization [81]. Moreover, if these lesions are not stopped or reversed through non-invasive treatments, they can evolve from early enamel lesions to dental caries, affecting both the enamel and dentin.

The relation between the main spectral features and the most frequent diseases of hard dental tissues is shown in Figure 4 and described in the paragraphs below.

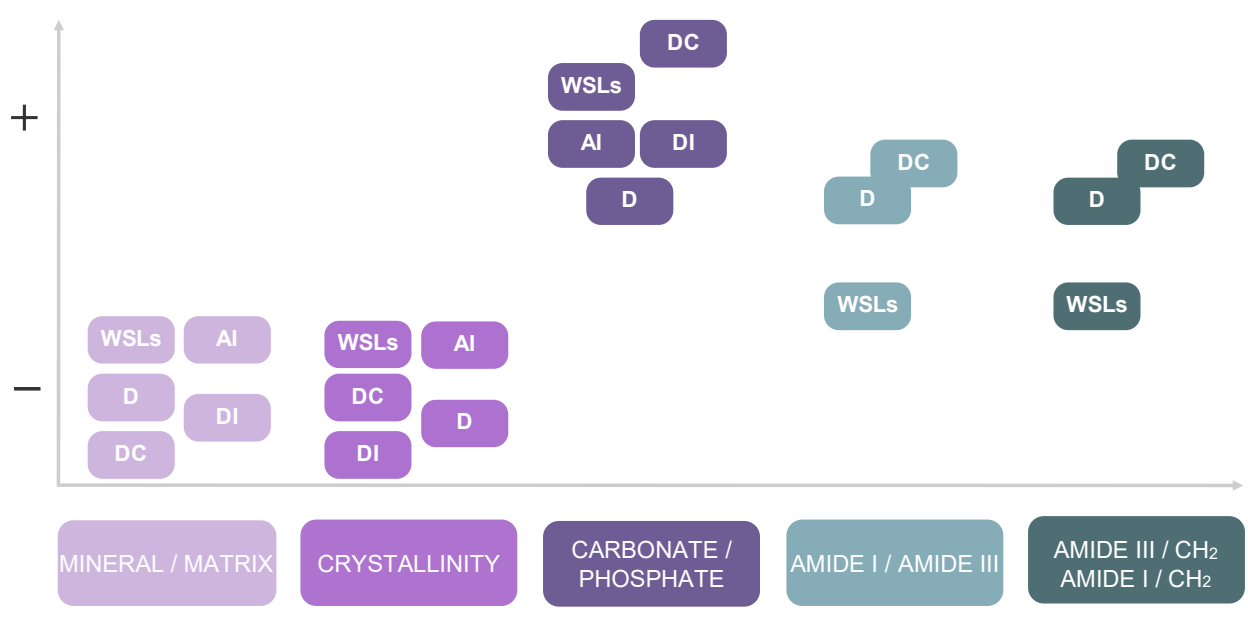

Figure 4. Variations of the main Raman-derived spectral parameters in relation to different dental pathologies (WSLs: white spot lesions; D: dentin; DC: dental caries; AI: amelogenesis imperfecta; DI: dentinogenesis imperfecta).

\subsection{RMS Study of Amelogenesis and Dentinogenesis Imperfectae}

The evaluation of enamel and dentin mineralization could be useful for the study of dental genetic anomalies, such as AI and DI [82]. Wright et al. reported increased levels of protein in AI enamel, even up to $30 \%$ in some types, with respect to sound enamel; however, no significant differences were found in the carbonate content between AI and sound enamel [83]. Moreover, in the study of Bērzinš et al., the authors suggested that a severely degraded AI tooth appeared to still include a small tier of highly ordered HA [84]. 
In another study, $\mathrm{C} / \mathrm{P}$ was found to be significantly higher in $\mathrm{AI}$ teeth compared to sound teeth [85].

In the case of DI, dentin possesses higher peak intensities of phosphate and amide III bands than normal dentin [86]. However, no significant differences were observed in the peak intensities of carbonate between DI and normal dentin. Additionally, C/P or GMC (carbonate-to-phosphate ratio or gradient in mineral content) was used to measure differences in relative composition, and a significant increment of GMC was found in DI-II dentin compared to normal dentin. Moreover, the ratio of amide I to amide III, relating to the organization of collagen, resulted in increased DGI-II dentin compared to normal dentin [86].

\subsection{RMS Characterization of Early Enamel Lesions}

The early detection of enamel lesions, as well as variations in the composition/structure of both enamel and dentin, represent important issues in modern dentistry. In this light, RMS is a valuable tool to detect carious lesions at an early stage of formation, since it allows for the collection of high-resolution maps and is highly sensitive to small changes in enamel composition [61].

The first clinically visible stage of carious disease is characterized by enamel demineralization without cavitation, known as white spot lesions (WSLs). However, in the absence of effective treatment, cavitation may occur, thereby increasing the necessity of invasive restorative treatments [87]. WSLs appear as milky white opaque spots on dental enamel. The translucency of enamel is an optical phenomenon that depends on the size of the intercrystalline spaces. In early stages, active caries require air drying to be visible, as the dissolution process of crystals at the outer enamel surface begins. Further enlargement of intercrystalline spaces results in a white patch that is visible without dryness. The effect of dehydration on enamel translucency is a result of the replacement of water content around enamel prisms with air. In a heterogeneous system, such as enamel prisms surrounded by a fluid medium, scattering occurs due to differences in the refractive indices (RI) of the two involved components. As the RI of enamel is approximately 1.65, while that of water is 1.33 and that of air is 1.00 , a greater difference among RI values produces a greater scattering at the enamel/air interface [88]. Ko et al. and Kinoshita et al. successfully provided Raman spectral imaging characterization for early caries [38,89]. Indeed, the high spatial resolution $(300 \mathrm{~nm})$ makes it an excellent tool for analyzing human enamel components, enabling the detection of WSLs at an early stage of development [21]. In order to define the levels of enamel demineralization after exposure to acid environments, some authors have analyzed the width of the bands related to phosphate vibrations (such as the band centered at $960 \mathrm{~cm}^{-1}$ ) [90].

In a recent study, chemical mapping of dental enamel was carried out over cross sections of specimens with natural and artificial WSLs [61]. The authors observed a severe decrease in the intensity of the $\mathrm{PO}_{4}{ }^{3-}$ peak in the area corresponding to the body of the lesion, with respect to sound enamel. A similar trend was shown by $\mathrm{C}$, which abruptly decreases in the lesion zone, while it starts to gradually increase in the intermediate zone, reaching its maximum value in sound enamel beyond the subsurface lesion. These findings are related to some alteration in crystal size and shape and, consequently, to reduced apatite perfection of the enamel prism. Finally, false color images derived from the $\mathrm{CO}_{3}{ }^{2-} / \mathrm{PO}_{4}{ }^{3-}$ ratio, used to analyze changes in enamel inorganic components in each zone of the lesion, revealed an increase in the ratio in the lesion, in comparison to sound enamel. Hence, it can be stated that in WSLs, enamel becomes less compact due to the increase of inter-prismatic voids, and less mineralized due to the decrease in mineral density and the increase in the organic matrix content [61].

\subsection{RMS Characterization of Dental Caries}

Dental caries is one of the most prevalent chronic diseases worldwide, affecting people throughout their lifetime [91]. It is an irreversible microbial disease that affects the calcified 
structures of the tooth. Despite several preventive measures aiming to reduce the incidence of this pathology, such as careful dental hygiene and the addition of fluorine to drinking water, the occurrence of caries is still one of the most common diseases experienced by most individuals [92]. It is known that the organic component can act as an inhibitor of hydroxyapatite crystals' growth during the processes of formation and development of caries, causing organic and inorganic biochemical alterations [68,93]. Therefore, a detailed analysis of these biochemical changes is mandatory to assess the best approach to help with remineralization of compromised dental tissue [94,95].

Current clinical diagnostic methods for dental caries detection are based on visual and radiographic examination; hence, they are unable to detect very early-stage lesions [96]. In this light, there is a need to develop new methods able to identify the presence of enamel caries before it is detectable with routine assays. RMS may provide this by characterizing the biochemical composition of healthy and carious enamel and dentine [97]. An in vitro study reported that polarized RMS showed a sensitivity of $97 \%$ and a specificity of $100 \%$ for the detection of caries [38]. Moreover, another recent study concluded that RMS can be used as a non-contact analytical technology for in vitro studies to discriminate with high resolution the zones of carious dentin tissues by using the amide I/phosphate v1 band ratio, calculated as the ratio between the areas of the bands at $1655 \mathrm{~cm}^{-1}$ and $960 \mathrm{~cm}^{-1}$, related to amide I of proteins and $v 1$ of phosphates, respectively [98].

In a previous study, the polarized Raman spectra of enamel, obtained after excitation with the $785 \mathrm{~nm}$ laser beam, was used to calculate the depolarization ratio and polarization anisotropy for distinguishing early carious processes. In sound enamel, apatite crystals are ordered in one direction, perpendicular to the enamel surface; in the presence of caries, this ordered arrangement is altered and the structure appears more disordered with enamel crystals that are not parallel to each other. In sound enamel, the depolarization ratio is low and the polarization anisotropy is high; conversely, the first increases and the latter decreases due to disordered carious enamel structure [99]. In the study of Buchwald et al., the authors highlighted some differences in the intensity, position, and FWHM of the $v_{1}$ band of phosphates at $960 \mathrm{~cm}^{-1}$ between sound and carious enamel. The simultaneous decreases of the value of the band intensity and FWHM were associated with a lower amount of apatite crystals in carious enamel [99]. It is important to check how these band parameters are affected by early demineralization of sound enamel under controlled conditions in order to define RMS as a reliable diagnostic tool in dentistry. Buchwald et al. observed that the values of the band position increase with enamel demineralization, and this shift to higher wavenumbers was attributed to changes in the vibrational energy of apatite crystals in demineralized enamel. These spectral modifications were also associated with a decrease in the amount of enamel phosphate and a reduction of the order of the structure [99].

Das Gupta et al. reported RMS chemical maps of enamel and dentin caries infiltration [78]. The enamel lesions appeared to be less mineralized due to more substituted carbonate in the crystal lattice compared to the sound enamel. When the lesion extends into the dentin, tissues have less mineral content than the sound dentin; however, many mineral apatites of caries are more crystalline and hence have less substituted carbonate in the lattice. Moreover, carious lesions have higher $C$ than the dentin but lower $C$ than enamel, and higher carbonate substitution in the lattice than enamel and dentin, which indicates the presence of crystals with less stoichiometric perfection in the caries lesion. In carious enamel, together with a decrease in the intensity of Raman peaks, differences in terms of band positions were also observed [99].

During the demineralization process in dentin, the band at $960 \mathrm{~cm}^{-1}$ becomes progressively lower, while the bands related to the organic component (amide I and amide III bands) did not show any change due to the acidic environment, thus proving that there is a progressive decrease in the fraction of the mineral phase with respect to that of the collagenous matrix [100]. Interestingly, the remineralization process appeared to increase the relative intensity of the $\mathrm{PO}_{4}{ }^{3-}$ bands only when dentin samples were treated in acidic 
solutions for less than $12 \mathrm{~h}$. As the $\mathrm{pH}$ of the demineralizing environment was decreased to a value of 2, the Raman intensity of the phosphate bands was further reduced, and samples lost the ability to recover any mineralization after just $6 \mathrm{~h}$ of acidic treatment. During demineralization, a non-linear correlation was found between the $\mathrm{M} / \mathrm{M}$ band ratio and $\mathrm{C}$ : $\mathrm{M} / \mathrm{M}$ decreases with the square power of $\mathrm{FWHM}_{960}$ [100]. The decrease in $\mathrm{M} / \mathrm{M}$ at a rate faster than the linear rate let hypothesize that the main rate-controlling phenomenon for structural recovery during remineralization is the deposition of new mineral crystals [100].

\section{Further and Newest Advances in RMS Applications}

Indeed, RMS is a rapidly emerging technique with medical applications in the early diagnosis of various types of pathologies, providing a unique "fingerprint" that enables the identification of characteristic chemical bonds [101].

To date, its use in dentistry has been focused on in vitro evaluations, but new innovative applications are being developed to exploit RMS in vivo. The most important difficulty in using Raman in vivo is the dimension of the instrument and the cost; however, Raman spectrometers have recently been miniaturized to pocket portable devices and can be converted to remote control by optical fibers. Hence, the availability of solid correlations with well-established spectroscopic techniques makes the Raman approach a quantitative tool for dental diagnostics that fits the preventive management of oral care required in modern dentistry [86]. The early identification of individuals with overall low mineralization of the enamel may be a valuable screening tool for determining a group with a much higher than average risk of caries, allowing intervention before the progression of decay. Indeed, optical probes could be used in time-lapse on the same patient, measuring the analyzed parameters, such as $\mathrm{M} / \mathrm{M}, \mathrm{C}$, and $\mathrm{C} / \mathrm{P}$, with a single measurement lasting a second. Such vibrational outputs could be also automatically converted into scores for clinical interpretation in a time-lapse fashion for individual patients [100].

With the development of advanced intraoral probes for clinical practice, the quality and quantity of bone could be analyzed, helping clinicians in predicting the prognosis and success rate of implant osseointegration. Fine intraoral probes could also be used to study the composition and other critical features of the newly formed bone adjacent to the implant (osseointegrated bone), thus providing information on bone maturation, implant stability, and the bone-implant interface [13].

Another potential application concerns the staging of osteonecrosis, which poses a challenging clinical situation since it is difficult to identify at an early stage [13,102]. Indeed, RMS analysis may reveal over-mineralization and ultrastructural modifications of the apatitic mineral in bone affected by osteonecrosis [102].

Thanks to the sensitivity of these new Raman-based fiber optical probe technologies, early interception of both genetic dental anomalies and enamel and dentin lesions can be achieved $[9,38,39]$. Moreover, many studies have demonstrated the use of RMS to distinguish between normal, pre-malignant, and malignant forms of oral mucosa $[37,103,104]$.

\section{Conclusions}

A narrative review regarding the application of Raman Microspectroscopy in the study of human hard dental tissues has been afforded. The decision to provide a narrative review could be considered as a limitation of the present work. However, it was made because the scientific literature is still scarce on this topic, since RMS represents an innovative analytical technique in dentistry. Thanks to light scattering, it is possible to perform chemical and structural imaging analyses of thick and solid samples, otherwise difficult to investigate, at a high spatial resolution level and in a confocal mode. Moreover, by the correlation between the morphology of the analyzed tissue with its chemical composition, it is possible to evaluate even miniscule changes in the macromolecular profile attributable to specific lesions or pathologies. Finally, the development of Raman devices mounting optical fibers could lead to the clinical translation of this vibrational technique to study dental lesions at an early stage when they are not visually detectable. 
Author Contributions: Conceptualization, G.O. (Giovanna Orsini), G.O. (Giulia Orilisi) and E.G.; methodology G.O. (Giulia Orilisi), V.N. and R.M.; validation R.M., F.V., V.T. and A.B.; investigation, G.O. (Giulia Orilisi), F.V. and A.B.; data curation, A.B., G.O. (Giulia Orilisi), V.N., R.M., F.V. and V.T.; writing-original draft preparation, G.O. (Giovanna Orsini), G.O. (Giulia Orilisi), V.N., R.M., F.V. and V.T.; writing-review and editing, G.O. (Giovanna Orsini), A.P. and E.G.; supervision, E.G., A.P. and G.O. (Giovanna Orsini). All authors have read and agreed to the published version of the manuscript.

Funding: This research received no external funding.

Institutional Review Board Statement: Not applicable.

Informed Consent Statement: Not applicable.

Data Availability Statement: The data presented in this study are available on request from the corresponding author.

Conflicts of Interest: The authors declare no conflict of interest.

\section{References}

1. Baker, M.J.; Trevisan, J.; Bassan, P.; Bhargava, R.; Butler, H.J.; Dorling, K.M.; Fielden, P.R.; Fogarty, S.W.; Fullwood, N.J.; Heys, K.A.; et al. Using Fourier Transform IR Spectroscopy to Analyze Biological Materials. Nat. Protoc. 2014, 9, 1771-1791. [CrossRef]

2. Notarstefano, V.; Belloni, A.; Sabbatini, S.; Pro, C.; Orilisi, G.; Monterubbianesi, R.; Tosco, V.; Byrne, H.J.; Vaccari, L.; Giorgini, E. Cytotoxic Effects of 5-Azacytidine on Primary Tumour Cells and Cancer Stem Cells from Oral Squamous Cell Carcinoma: An In Vitro FTIRM Analysis. Cells 2021, 10, 2127. [CrossRef]

3. Notarstefano, V.; Sabbatini, S.; Conti, C.; Pisani, M.; Astolfi, P.; Pro, C.; Rubini, C.; Vaccari, L.; Giorgini, E. Investigation of Human Pancreatic Cancer Tissues by Fourier Transform Infrared Hyperspectral Imaging. J. Biophotonics 2020, 13, e201960071. [CrossRef]

4. Geraldes, C.F.G.C. Introduction to Infrared and Raman-Based Biomedical Molecular Imaging and Comparison with Other Modalities. Molecules 2020, 25, 5547. [CrossRef] [PubMed]

5. Diem, M. Modern Vibrational Spectroscopy and MicroSpectroscopy: Theory, Instrumentation and Biomedical Applications; John Wiley \& Sons, Ltd.: Hoboken, NJ, USA, 2015; ISBN 9781118824863.

6. Hanlon, E.B.; Manoharan, R.; Koo, T.W.; Shafer, K.E.; Motz, J.T.; Fitzmaurice, M.; Kramer, J.R.; Itzkan, I.; Dasari, R.R.; Feld, M.S. Prospects for in Vivo Raman Spectroscopy. Phys. Med. Biol. 2000, 45, R1-R59. [CrossRef] [PubMed]

7. Butler, H.J.; Ashton, L.; Bird, B.; Cinque, G.; Curtis, K.; Dorney, J.; Esmonde-White, K.; Fullwood, N.J.; Gardner, B.; Martin-Hirsch, P.L.; et al. Using Raman Spectroscopy to Characterize Biological Materials. Nat. Protoc. 2016, 11, 664-687. [CrossRef] [PubMed]

8. Larkin, P.J. Infrared and Raman Spectroscopy, 2nd ed.; Elsevier: Amsterdam, The Netherlands, 2018; pp. 1-5. ISBN 978-0-12-804162-8.

9. Krafft, C.; Sergo, V. Biomedical Applications of Raman and Infrared Spectroscopy to Diagnose Tissues. J. Spectrosc. 2006, 20, 738186. [CrossRef]

10. Griffiths, P.R. Handbook of Vibrational Spectroscopy; John Wiley \& Sons, Ltd.: Hoboken, NJ, USA, 2010; ISBN 978-0-470-02732-5.

11. Stuart, B. Infrared Spectroscopy: Fundamentals and Applications; John Wiley \& Sons, Ltd.: Hoboken, NJ, USA, 2004; pp. 137-165; ISBN 978-0-470-01114-0.

12. Kowalczuk, D.; Pitucha, M. Application of FTIR Method for the Assessment of Immobilization of Active Substances in the Matrix of Biomedical Materials. Materials 2019, 12, 2927. [CrossRef]

13. Ramakrishnaiah, R.; Rehman, G.U.; Basavarajappa, S.; Khuraif, A.A.A.; Durgesh, B.H.; Khan, A.S.; Rehman, I.U. Applications of Raman Spectroscopy in Dentistry: Analysis of Tooth Structure. Appl. Spectrosc. Rev. 2015, 50, 332-350. [CrossRef]

14. Kekkonen, J.; Finnilä, M.A.J.; Heikkilä, J.; Anttonen, V.; Nissinen, I. Chemical Imaging of Human Teeth by a Time-Resolved Raman Spectrometer Based on a CMOS Single-Photon Avalanche Diode Line Sensor. Analyst 2019, 144, 6089-6097. [CrossRef]

15. Smith, E.; Dent, G. Modern Raman Spectroscopy: A Practical Approach; Wiley and Sons, Ltd.: Hoboken, NJ, USA, 2005; ISBN 978-0471-49794-3.

16. Akkus, A.; Yang, S.; Roperto, R.; Mustafa, H.; Teich, S.; Akkus, O. A Portable Fiber-Optic Raman Spectrometer Concept for Evaluation of Mineral Content within Enamel Tissue. J. Clin. Exp. Dent. 2017, 9, e238-e241. [CrossRef] [PubMed]

17. Paschalis, E.P.; Gamsjaeger, S.; Klaushofer, K. Vibrational Spectroscopic Techniques to Assess Bone Quality. Osteoporos. Int. 2017, 28, 2275-2291. [CrossRef]

18. Pahlow, S.; Weber, K.; Popp, J.; Wood, B.R.; Kochan, K.; Rüther, A.; Perez-Guaita, D.; Heraud, P.; Stone, N.; Dudgeon, A.; et al. Application of Vibrational Spectroscopy and Imaging to Point-of-Care Medicine: A Review. Appl. Spectrosc. 2018, 72, 52-84. [CrossRef]

19. Carden, A.; Morris, M.D. Application of Vibrational Spectroscopy to the Study of Mineralized Tissues (Review). J. Biomed. Opt. 2000, 5, 259-268. [CrossRef] [PubMed] 
20. Torres, C.P.; Miranda Gomes-Silva, J.; Menezes-Oliveira, M.A.H.; Silva Soares, L.E.; Palma-Dibb, R.G.; Borsatto, M.C. FT-Raman Spectroscopy, $\mu$-EDXRF Spectrometry, and Microhardness Analysis of the Dentin of Primary and Permanent Teeth. Microsc. Res. Tech. 2018, 81, 509-514. [CrossRef] [PubMed]

21. Desoutter, A.; Slimani, A.; Al-Obaidi, R.; Barthélemi, S.; Cuisinier, F.; Tassery, H.; Salehi, H. Cross Striation in Human Permanent and Deciduous Enamel Measured with Confocal Raman Microscopy. J. Raman Spectrosc. 2019, 50, 548-556. [CrossRef]

22. Taylor, E.A.; Lloyd, A.A.; Salazar-Lara, C.; Donnelly, E. Raman and Fourier Transform Infrared (FT-IR) Mineral to Matrix Ratios Correlate with Physical Chemical Properties of Model Compounds and Native Bone Tissue. Appl. Spectrosc. 2017, 71, 2404-2410. [CrossRef] [PubMed]

23. Kaczmarek, K.; Leniart, A.; Lapinska, B.; Skrzypek, S.; Lukomska-Szymanska, M. Selected Spectroscopic Techniques for Surface Analysis of Dental Materials: A Narrative Review. Materials 2021, 14, 2624. [CrossRef]

24. Monterubbianesi, R.; Tosco, V.; Sabbatini, S.; Orilisi, G.; Conti, C.; Özcan, M.; Orsini, G.; Putignano, A. How Can Different Polishing Timing Influence Methacrylate and Dimethacrylate Bulk Fill Composites? Evaluation of Chemical and Physical Properties. Biomed Res. Int. 2020, 2020, 1965818. [CrossRef]

25. Tosco, V.; Monterubbianesi, R.; Orilisi, G.; Sabbatini, S.; Conti, C.; Özcan, M.; Putignano, A.; Orsini, G. Comparison of Two Curing Protocols during Adhesive Cementation: Can the Step Luting Technique Supersede the Traditional One? Odontology 2021, 109, 433-439. [CrossRef]

26. Shim, J.S.; Lee, S.Y.; Song, S.-Y.; Jha, N.; Ryu, J.J. Polymerization Efficiency of Dental Dual-Cured Resin Cement Light-Cured at Various Times after the Initiation of Chemical Activation. Int. J. Polym. Mater. Polym. Biomater. 2020, 69, 622-628. [CrossRef]

27. Monterubbianesi, R.; Orsini, G.; Tosi, G.; Conti, C.; Librando, V.; Procaccini, M.; Putignano, A. Spectroscopic and Mechanical Properties of a New Generation of Bulk Fill Composites. Front. Physiol. 2016, 7, 652. [CrossRef]

28. Fugolin, A.P.; Lewis, S.; Logan, M.G.; Ferracane, J.L.; Pfeifer, C.S. Methacrylamide-Methacrylate Hybrid Monomers for Dental Applications. Dent. Mater. 2020, 36, 1028-1037. [CrossRef]

29. Fugolin, A.P.P.; Navarro, O.; Logan, M.G.; Huynh, V.; França, C.M.; Ferracane, J.L.; Pfeifer, C.S. Synthesis of Di- and Triacrylamides with Tertiary Amine Cores and Their Evaluation as Monomers in Dental Adhesive Interfaces. Acta Biomater. 2020, 115, 148-159. [CrossRef] [PubMed]

30. Lelli, M.; Putignano, A.; Marchetti, M.; Foltran, I.; Mangani, F.; Procaccini, M.; Roveri, N.; Orsini, G. Remineralization and Repair of Enamel Surface by Biomimetic Zn-Carbonate Hydroxyapatite Containing Toothpaste: A Comparative in Vivo Study. Front. Physiol. 2014, 5, 333. [CrossRef]

31. Orilisi, G.; Tosco, V.; Monterubbianesi, R.; Notarstefano, V.; Özcan, M.; Putignano, A.; Orsini, G. ATR-FTIR, EDS and SEM Evaluations of Enamel Structure after Treatment with Hydrogen Peroxide Bleaching Agents Loaded with Nano-Hydroxyapatite Particles. PeerJ 2021, 9, e10606. [CrossRef] [PubMed]

32. Seredin, P.V.; Uspenskaya, O.A.; Goloshchapov, D.L.; Ippolitov, I.Y.; Vongsvivut, J.P.; Ippolitov, Y.A. Organic-Mineral Interaction between Biomimetic Materials and Hard Dental Tissues. Sovrem. Tekhnologii Med. 2020, 12, 43-50. [CrossRef] [PubMed]

33. Gurgenc, T. Structural Characterization and Dielectrical Properties of Ag-Doped Nano-Strontium Apatite Particles Produced by Hydrothermal Method. J. Mol. Struct. 2021, 1223, 128990. [CrossRef]

34. Wulfman, C.; Sadoun, M.; Lamy de la Chapelle, M. Interest of Raman Spectroscopy for the Study of Dental Material: The Zirconia Material Example. IRBM 2010, 31, 257-262. [CrossRef]

35. Silikas, N.; Eliades, G.; Watts, D.C. Light Intensity Effects on Resin-Composite Degree of Conversion and Shrinkage Strain. Dent. Mater. 2000, 16, 292-296. [CrossRef]

36. Arnold, W.H.; Gaengler, P. Quantitative Analysis of the Calcium and Phosphorus Content of Developing and Permanent Human Teeth. Ann. Anat. 2007, 189, 183-190. [CrossRef]

37. Jeng, M.-J.; Sharma, M.; Sharma, L.; Chao, T.-Y.; Huang, S.-F.; Chang, L.-B.; Wu, S.-L.; Chow, L. Raman Spectroscopy Analysis for Optical Diagnosis of Oral Cancer Detection. J. Clin. Med. 2019, 8, 1313. [CrossRef]

38. Ko, A.C.-T.; Choo-Smith, L.-P.; Hewko, M.; Sowa, M.G.; Dong, C.C.S.; Cleghorn, B. Detection of Early Dental Caries Using Polarized Raman Spectroscopy. Opt. Express 2006, 14, 203-215. [CrossRef] [PubMed]

39. Ko, A.C.-T.; Hewko, M.; Sowa, M.G.; Dong, C.C.S.; Cleghorn, B.; Choo-Smith, L.-P. Early Dental Caries Detection Using a Fibre-Optic Coupled Polarization-Resolved Raman Spectroscopic System. Opt. Express 2008, 16, 6274-6284. [CrossRef]

40. Seredin, P.; Goloshchapov, D.; Ippolitov, Y.; Vongsvivut, J. Development of a New Approach to Diagnosis of the Early Fluorosis Forms by Means of FTIR and Raman Microspectroscopy. Sci. Rep. 2020, 10, 20891. [CrossRef] [PubMed]

41. Anwar Alebrahim, M.; Krafft, C.; Sekhaneh, W.; Sigusch, B.; Popp, J. ATR-FTIR and Raman Spectroscopy of Primary and Permanent Teeth. Biomed. Spectrosc. Imaging 2014, 3, 15-27. [CrossRef]

42. Besnard, C.; Harper, R.A.; Salvati, E.; Moxham, T.E.J.; Romano Brandt, L.; Landini, G.; Shelton, R.M.; Korsunsky, A.M. Analysis of in Vitro Demineralised Human Enamel Using Multi-Scale Correlative Optical and Scanning Electron Microscopy, and HighResolution Synchrotron Wide-Angle X-Ray Scattering. Mater. Des. 2021, 206, 109739. [CrossRef]

43. De Menezes Oliveira, M.A.H.; Torres, C.P.; Gomes-Silva, J.M.; Chinelatti, M.A.; De Menezes, F.C.H.; Palma-Dibb, R.G.; Borsatto, M.C. Microstructure and Mineral Composition of Dental Enamel of Permanent and Deciduous Teeth. Microsc. Res. Tech. 2010, 73, 572-577. [CrossRef] 
44. Putignano, A.; Tosco, V.; Monterubbianesi, R.; Vitiello, F.; Gatto, M.L.; Furlani, M.; Giuliani, A.; Orsini, G. Comparison of Three Different Bulk-Filling Techniques for Restoring Class II Cavities: MCT, SEM-EDS Combined Analyses for Margins and Internal Fit Assessments. J. Mech. Behav. Biomed. Mater. 2021, 124, 104812. [CrossRef]

45. Sabel, N.; Karlsson, A.; Sjölin, L. XRMA Analysis and X-Ray Diffraction Analysis of Dental Enamel from Human Permanent Teeth Exposed to Hydrogen Peroxide of Varying PH. J. Clin. Exp. Dent. 2019, 11, e512-e520. [CrossRef]

46. Kondo, S.; Manabe, Y. Analytical Methods and Interpretation of Variation in Tooth Morphology. J. Oral Biosci. 2016, 58, 85-94. [CrossRef]

47. Tosco, V.; Vitiello, F.; Furlani, M.; Gatto, M.L.; Monterubbianesi, R.; Giuliani, A.; Orsini, G.; Putignano, A. Microleakage Analysis of Different Bulk-Filling Techniques for Class II Restorations: M-CT, SEM and EDS Evaluations. Materials 2020, 14, 31. [CrossRef] [PubMed]

48. Orilisi, G.; Monterubbianesi, R.; Notarstefano, V.; Tosco, V.; Vitiello, F.; Giuliani, G.; Putignano, A.; Orsini, G. New Insights from Raman MicroSpectroscopy and Scanning Electron Microscopy on the Microstructure and Chemical Composition of Vestibular and Lingual Surfaces in Permanent and Deciduous Human Teeth. Spectrochim. Acta A Mol. Biomol. Spectrosc. 2021, $260,119966$. [CrossRef]

49. Lee, J.-Y.; Kim, H.-J.; Lee, E.-S.; de Josselin de Jong, E.; Jung, H.-I.; Kim, B.-I. Quantitative Light-Induced Fluorescence as a Potential Tool for Detection of Enamel Chemical Composition. Photodiagnosis Photodyn. Ther. 2020, 32, 102054. [CrossRef] [PubMed]

50. Baethge, C.; Goldbeck-Wood, S.; Mertens, S. SANRA—a Scale for the Quality Assessment of Narrative Review Articles. Res. Integr. Peer Rev. 2019, 4, 5. [CrossRef] [PubMed]

51. Green, B.N.; Johnson, C.D.; Adams, A. Writing Narrative Literature Reviews for Peer-Reviewed Journals: Secrets of the Trade. J. Chiropr. Med. 2006, 5, 101-117. [CrossRef]

52. Lacruz, R.S.; Habelitz, S.; Wright, J.T.; Paine, M.L. Dental Enamel Formation and Implications for Oral Health and Disease. Physiol. Rev. 2017, 97, 939-993. [CrossRef]

53. Nanci, A. Ten Cate's Oral Histology: Development, Structure and Function, 9th ed.; Elsevier: Amsterdam, The Netherlands, 2020; ISBN 9789696379393.

54. Srivastava, K.; Tikku, T.; Khanna, R.; Sachan, K. Risk Factors and Management of White Spot Lesions in Orthodontics. J. Orthod. Sci. 2013, 2, 43-49. [CrossRef]

55. Yamamoto, T.; Hasegawa, T.; Yamamoto, T.; Hongo, H.; Amizuka, N. Histology of Human Cementum: Its Structure, Function, and Development. Jpn. Dent. Sci. Rev. 2016, 52, 63-74. [CrossRef] [PubMed]

56. Shellis, R.P. Relationship between Human Enamel Structure and the Formation of Caries-like Lesions in Vitro. Arch. Oral. Biol. 1984, 29, 975-981. [CrossRef]

57. Targino, A.G.R.; Rosenblatt, A.; Oliveira, A.F.; Chaves, A.M.B.; Santos, V.E. The Relationship of Enamel Defects and Caries: A Cohort Study. Oral Dis. 2011, 17, 420-426. [CrossRef] [PubMed]

58. Efeoglu, N.; Wood, D.; Efeoglu, C. Microcomputerised Tomography Evaluation of 10\% Carbamide Peroxide Applied to Enamel. J. Dent. 2005, 33, 561-567. [CrossRef]

59. Efeoglu, N.; Wood, D.J.; Efeoglu, C. Thirty-Five Percent Carbamide Peroxide Application Causes In Vitro Demineralization of Enamel. Dent. Mater. 2007, 23, 900-904. [CrossRef]

60. Penel, G.; Leroy, G.; Rey, C.; Bres, E. MicroRaman Spectral Study of the PO4 and CO3 Vibrational Modes in Synthetic and Biological Apatites. Calcif. Tissue Int. 1998, 63, 475-481. [CrossRef]

61. Al-Obaidi, R.; Salehi, H.; Desoutter, A.; Bonnet, L.; Etienne, P.; Terrer, E.; Jacquot, B.; Levallois, B.; Tassery, H.; Cuisinier, F.J.G. Chemical \& Nano-Mechanical Study of Artificial Human Enamel Subsurface Lesions. Sci. Rep. 2018, 8, 4047. [CrossRef] [PubMed]

62. Akgun, O.M.; Haman Bayari, S.; Ide, S.; Guven Polat, G.; Yildirim, C.; Orujalipoor, I. Evaluation of the Protective Effect on Enamel Demineralization of CPP-ACP Paste and ROCS by Vibrational Spectroscopy and SAXS: An in Vitro Study. Microsc. Res. Tech. 2021, 84, 2977-2987. [CrossRef]

63. Fulmer, M.T.; Ison, I.C.; Hankermayer, C.R.; Constantz, B.R.; Ross, J. Measurements of the Solubilities and Dissolution Rates of Several Hydroxyapatites. Biomaterials 2002, 23, 751-755. [CrossRef]

64. Borges, A.F.S.; Bitar, R.A.; Kantovitz, K.R.; Correr, A.B.; Martin, A.A.; Puppin-Rontani, R.M. New Perspectives about Molecular Arrangement of Primary and Permanent Dentin. Appl. Surf. Sci. 2007, 254, 1498-1505. [CrossRef]

65. Schaffner, M.; Lussi, A. Developmental and Histological Aspects of Deciduous and Young Permanent Teeth. In Management of Dental Emergencies in Children and Adolescents, 1st ed; John Wiley \& Sons, Ltd.: Hoboken, NJ, USA, 2019; ISBN 978-1-119-37264-6.

66. Xu, C.; Reed, R.; Gorski, J.P.; Wang, Y.; Walker, M.P. The Distribution of Carbonate in Enamel and Its Correlation with Structure and Mechanical Properties. J. Mater. Sci. 2012, 47, 8035-8043. [CrossRef]

67. Khalid, M.; Bora, T.; Ghaithi, A.A.; Thukral, S.; Dutta, J. Raman Spectroscopy Detects Changes in Bone Mineral Quality and Collagen Cross-Linkage in Staphylococcus Infected Human Bone. Sci. Rep. 2018, 8, 9417. [CrossRef]

68. Liu, Y.; Yao, X.; Liu, Y.; Wang, Y. A Fourier Transform Infrared Spectroscopy Analysis of Carious Dentin from Transparent Zone to Normal Zone. Caries Res. 2014, 48, 320-329. [CrossRef] [PubMed]

69. Almhöjd, U.S.; Norén, J.G.; Arvidsson, A.; Nilsson, Å.; Lingström, P. Analysis of Carious Dentine Using FTIR and ToF-SIMS. Oral Health Dent. Manag. 2014, 13, 735-744. [PubMed] 
70. Slimani, A.; Nouioua, F.; Desoutter, A.; Levallois, B.; Cuisinier, F.J.G.; Tassery, H.; Terrer, E.; Salehi, H. Confocal Raman Mapping of Collagen Cross-Link and Crystallinity of Human Dentin-Enamel Junction. J. Biomed. Opt. 2017, 22, 086003. [CrossRef]

71. Enrich-Essvein, T.; Benavides-Reyes, C.; Álvarez-Lloret, P.; Bolaños-Carmona, M.V.; Rodríguez-Navarro, A.B.; González-López, S. Influence of De-Remineralization Process on Chemical, Microstructural, and Mechanical Properties of Human and Bovine Dentin. Clin. Oral Investig. 2021, 25, 841-849. [CrossRef]

72. Ortiz-Ruiz, A.J.; de Dios Teruel-Fernández, J.; Alcolea-Rubio, L.A.; Hernández-Fernández, A.; Martínez-Beneyto, Y.; GispertGuirado, F. Structural Differences in Enamel and Dentin in Human, Bovine, Porcine, and Ovine Teeth. Ann. Anat. 2018, $218,7-17$. [CrossRef]

73. Salehi, H.; Terrer, E.; Panayotov, I.; Levallois, B.; Jacquot, B.; Tassery, H.; Cuisinier, F. Functional Mapping of Human Sound and Carious Enamel and Dentin with Raman Spectroscopy. J. Biophotonics 2013, 6, 765-774. [CrossRef]

74. Toledano, M.; Aguilera, F.S.; Osorio, E.; Cabello, I.; Toledano-Osorio, M.; Osorio, R. Functional and Molecular Structural Analysis of Dentine Interfaces Promoted by a Zn-Doped Self-Etching Adhesive and an in Vitro Load Cycling Model. J. Mech. Behav. Biomed. Mater. 2015, 50, 131-149. [CrossRef]

75. Widbiller, M.; Rothmaier, C.; Saliter, D.; Wölflick, M.; Rosendahl, A.; Buchalla, W.; Schmalz, G.; Spruss, T.; Galler, K.M. Histology of Human Teeth: Standard and Specific Staining Methods Revisited. Arch. Oral Biol. 2021, 127, 105136. [CrossRef] [PubMed]

76. Orsini, G.; Bianchi, A.E.; Vinci, R.; Piattelli, A. Histologic Evaluation of Autogenous Calvarial Bone in Maxillary Onlay Bone Grafts: A Report of 2 Cases. Int. J. Oral Maxillofac. Implants 2003, 18, 594-598.

77. Hewko, M.D.; Choo-Smith, L.-P.; Ko, A.C.-T.; Leonardi, L.; Dong, C.C.S.; Cleghorn, B.; Sowa, M.G. OCT of Early Dental Caries: A Comparative Study with Histology and Raman Spectroscopy. In Lasers in Dentistry XI; SPIE BiOS: San Jose, CA, USA; Bellingham, WA, USA, 2005; Volume 5687, pp. 16-24.

78. Das Gupta, S.; Killenberger, M.; Tanner, T.; Rieppo, L.; Saarakkala, S.; Heikkilä, J.; Anttonen, V.; Finnilä, M.A.J. Mineralization of Dental Tissues and Caries Lesions Detailed with Raman Microspectroscopic Imaging. Analyst 2021, 146, 1705-1713. [CrossRef] [PubMed]

79. Smith, C.E.L.; Poulter, J.A.; Antanaviciute, A.; Kirkham, J.; Brookes, S.J.; Inglehearn, C.F.; Mighell, A.J. Amelogenesis Imperfecta; Genes, Proteins, and Pathways. Front. Physiol. 2017, 8, 435. [CrossRef]

80. Gadhia, K.; McDonald, S.; Arkutu, N.; Malik, K. Amelogenesis Imperfecta: An Introduction. Br. Dent. J. 2012, 212, 377-379. [CrossRef]

81. Akkus, A.; Akkus, A.; Roperto, R.; Akkus, O.; Porto, T.; Teich, S.; Lang, L. Evaluation of Mineral Content in Healthy Permanent Human Enamel by Raman Spectroscopy. J. Clin. Exp. Dent. 2016, 8, e546-e549. [CrossRef] [PubMed]

82. Orsini, G.; Majorana, A.; Mazzoni, A.; Putignano, A.; Falconi, M.; Polimeni, A.; Breschi, L. Immunocytochemical Detection of Dentin Matrix Proteins in Primary Teeth from Patients with Dentinogenesis Imperfecta Associated with Osteogenesis Imperfecta. Eur. J. Histochem. 2014, 58, 301-306. [CrossRef]

83. Wright, J.T.; Duggal, M.S.; Robinson, C.; Kirkham, J.; Shore, R. The Mineral Composition and Enamel Ultrastructure of Hypocalcified Amelogenesis Imperfecta. J. Craniofac. Genet. Dev. Biol. 1993, 13, 117-126. [PubMed]

84. Bērziňš, K.; Sutton, J.J.; Loch, C.; Beckett, D.; Wheeler, B.J.; Drummond, B.K.; Fraser-Miller, S.J.; Gordon, K.C. Application of Low-Wavenumber Raman Spectroscopy to the Analysis of Human Teeth. J. Raman Spectrosc. 2019, 50, 1375-1387. [CrossRef]

85. Crombie, F.A.; Manton, D.J.; Palamara, J.E.A.; Zalizniak, I.; Cochrane, N.J.; Reynolds, E.C. Characterisation of Developmentally Hypomineralised Human Enamel. J Dent. 2013, 41, 611-618. [CrossRef]

86. Mao, J.; Wang, L.; Jiang, Y.; Cheng, H.; Li, N.; Shi, S.; Fan, F.; Ma, J.; Huang, S. Nanoscopic Wear Behavior of Dentinogenesis Imperfecta Type II Tooth Dentin. J. Mech. Behav. Biomed. Mater. 2021, 120, 104585. [CrossRef]

87. Bergstrand, F.; Twetman, S. A Review on Prevention and Treatment of Post-Orthodontic White Spot Lesions-Evidence-Based Methods and Emerging Technologies. Open Dent. J. 2011, 5, 158-162. [CrossRef] [PubMed]

88. Guerra, F.; Mazur, M.; Corridore, D.; Pasqualotto, D.; Rinaldo, F.; Ottolenghi, L. Dental Hypomineralized Enamel Resin Infiltration. Clinical Indications and Limits. Senses Sci. 2015, 2, 135-139. [CrossRef]

89. Kinoshita, H.; Miyoshi, N.; Fukunaga, Y.; Ogawa, T.; Ogasawara, T.; Sano, K. Functional Mapping of Carious Enamel in Human Teeth with Raman Microspectroscopy. J. Raman Spectrosc. 2008, 39, 655-660. [CrossRef]

90. Pezzotti, G.; Adachi, T.; Gasparutti, I.; Vincini, G.; Zhu, W.; Boffelli, M.; Rondinella, A.; Marin, E.; Ichioka, H.; Yamamoto, T.; et al. Vibrational Monitor of Early Demineralization in Tooth Enamel after in Vitro Exposure to Phosphoridic Liquid. Spectrochim. Acta A Mol. Biomol. Spectrosc. 2017, 173, 19-33. [CrossRef]

91. Dental Caries among Adults and Older Adults. Available online: https://www.cdc.gov/oralhealth/publications/OHSR-2019 -dental-carries-adults.html (accessed on 12 December 2021).

92. Matousek, P.; Morris, M. (Eds.) Emerging Raman Applications and Techniques in Biomedical and Pharmaceutical Fields; Biological and Medical Physics, Biomedical Engineering; Springer: Berlin/Heidelberg, Germany, 2010; ISBN 978-3-642-02648-5.

93. Seredin, P.; Goloshchapov, D.; Prutskij, T.; Ippolitov, Y. Phase Transformations in a Human Tooth Tissue at the Initial Stage of Caries. PLoS ONE 2015, 10, e0124008. [CrossRef]

94. Ali, A.; Almaroof, A.; Festy, F.; Banerjee, A.; Mannocci, F. In Vitro Remineralization of Caries-Affected Dentin after Selective Carious Tissue Removal. World J. Dent. 2018, 9, 170-179. [CrossRef]

95. Tosco, V.; Monterubbianesi, R.; Sparabombe, S.; Orilisi, G.; Putignano, A.; Orsini, G. In Vitro Investigation of the Effect of Different Remineralizing Agents on Human Enamel. Mod. App. Dent. Oral Health 2020, 4, 369-375. [CrossRef] 
96. Pretty, I.A. Caries Detection and Diagnosis: Novel Technologies. J. Dent. 2006, 34, 727-739. [CrossRef]

97. Ando, M.; Liao, C.-S.; Eckert, G.J.; Cheng, J.-X. Imaging of Demineralized Enamel in Intact Tooth by Epidetected Stimulated Raman Scattering Microscopy. J. Biomed. Opt. 2018, 23, 105005. [CrossRef] [PubMed]

98. Alturki, M.; Koller, G.; Warburton, F.; Almhöjd, U.; Banerjee, A. Biochemical Characterisation of Carious Dentine Zones Using Raman Spectroscopy. J. Dent. 2021, 105, 103558. [CrossRef] [PubMed]

99. Buchwald, T.; Buchwald, Z. Assessment of the Raman Spectroscopy Effectiveness in Determining the Early Changes in Human Enamel Caused by Artificial Caries. Analyst 2019, 144, 1409-1419. [CrossRef]

100. Marin, E.; Hiraishi, N.; Honma, T.; Boschetto, F.; Zanocco, M.; Zhu, W.; Adachi, T.; Kanamura, N.; Yamamoto, T.; Pezzotti, G. Raman Spectroscopy for Early Detection and Monitoring of Dentin Demineralization. Dent. Mater. 2020, 36, 1635-1644. [CrossRef]

101. Vašková, H. A Powerful Tool for Material Identification: Raman Spectroscopy. Int. J. Math. Model. Methods Appl. Sci. 2011, 5, 1205-1212.

102. Olejnik, C.; Falgayrac, G.; During, A.; Vieillard, M.H.; Maes, J.M.; Cortet, B.; Penel, G. Molecular Alterations of Bone Quality in Sequesters of Bisphosphonates-Related Osteonecrosis of the Jaws. Osteoporos. Int. 2014, 25, 747-756. [CrossRef] [PubMed]

103. Dai, W.-Y.; Lee, S.; Hsu, Y.-C. Discrimination between Oral Cancer and Healthy Cells Based on the Adenine Signature Detected by Using Raman Spectroscopy. J. Raman Spectrosc. 2018, 49, 336-342. [CrossRef]

104. Guze, K.; Pawluk, H.C.; Short, M.; Zeng, H.; Lorch, J.; Norris, C.; Sonis, S. Pilot Study: Raman Spectroscopy in Differentiating Premalignant and Malignant Oral Lesions from Normal Mucosa and Benign Lesions in Humans. Head Neck 2015, 37, 511-517. [CrossRef] [PubMed] 